\title{
食品安全委員会の現状と今後
}

\author{
山本茂貴
}

内閣府食品安全委員会

\section{Present and Future of Food Safety Commission Japan}

\author{
Shigeki Yамамото \\ Food Safety Commission of Japan
}

\section{はじめに}

食生活が豊かになる一方, 食生活を取り巻く環境は近 年大きく変化し, 食に対する関心が高まっています。こ のような情勢のなか, 国際的には, コーデックス委員会 が国際的食品規格等について決定しています。その際, リスクアナリシスの考え方に基づき，国際規格を決定し ています。リスクアナリシスには, リスク管理, リスク 評価, リスクコミュニケーションの三つの要素がありま す。コーデックス委員会はリスクアナリシスの考え方を 食品安全行政の枠組みに導入することを推奨しています。

こうした情勢の変化に的確に対応するため, 食品安全 基本法が制定され，これに基づいて新たな食品安全行政 を展開していくことになり，これに伴い，食品安全委員 会が平成 15 年 7 月 1 日に, 新たに内閣府に設置されまし た.

食品安全委員会は，国民の健康の保護が最も重要であ るという基本的認識の下, 規制や指導等のリスク管理を 行う関係行政機関から独立して, 科学的知見に基づき客 観的かつ中立公正にリスク評価を行う機関です.

食品安全委員会は7名の委員から構成され，その下に 12 の専門調查会が設置されています.

専門調査会は, 企画等専門調査会に加え, 添加物, 農 薬, 微生物といった危害要因ごとに11の専門調査会が 設置されています.

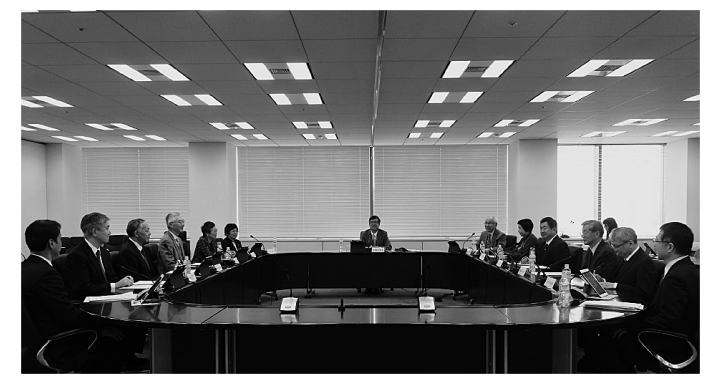

食品安全委員会会議風景（食品安全委員会HPょり）
また，事務局は，事務局長，次長，総務課，評価第一 課，評価技術企画室，評価第二課，情報・锥告広報課， リスクコミュニケーション官, 評価情報分析官から構成 されています.

食品安全委員会のやるべきこととして，1. 食品健康 影響評価 (リスク評価)，2. リスクコミュニケーション， 3. 研究および調查事業, 4. 国際協力, 5. 食品衛生行政 の監視, 6. 食品安全における危機対応の六つがありま す.

\section{1. 食品健康影響評価（リスク評価）}

コーデックス委員会によると, リスク評価は(1)危害要 因特定, (2)危害要因判定, (3)゙くろ評価, (4)リスク判定 の四つの段階を含んでいます.

食品安全委員会におけるリスク評価は, 食品健康影響 評価と呼ばれています。

食品健康影響評価を行うことは食品安全委員会の最も 重要な役割で食品安全基本法に規定されています。食品 健康影響評価とは, 食品に含まれる添加物, 農薬や微生 物などの危害要因がヒトの健康に与える影響についてリ スク評価を行うことです。具体的には, 食品中の危害要 因を摂取することによって, どの程度の量の危害要因を 摂取すると, どのくらいの確率でどのくらい深刻に健康 への影響が起きるかを科学的に評価します。ただし, 農 薬については, 現在, 一日摂取許容量の設定までを行っ ています。

食品安全委員会では，主として厚生労働省，農林水産 省, 消費者庁などのリスク管理機関からの評価要請を受 けてリスク評価を実施するほか, リスク管理機関から評 価を要請されなくとも評価を行う必要があると考えられ る場合には，「自ら評価」と呼ばれるリスク評価も実施 しています.

設立以来, 食品安全委員会では, 平成 29 年 3 月末で 2,338件のリスク評価を実施しました。

さらに，食品安全委員会は，リスク評価の結果に基づ 

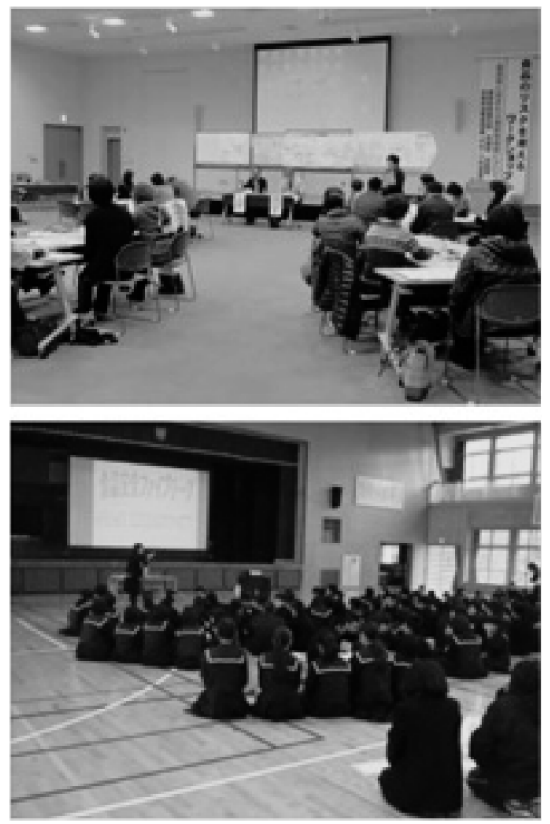

リスクコミュニケーションの様子（食品安全委員会 HPより）

いて行われるべき施策についてリスク管理機関に勧告を 行うことができます.

\section{2. リスクコミュニケーション}

リスク評価やリスク管理を行っていく上で，透明性を 確保しつつ国民の理解を進めていくためには, リスクコ ミュニケーションが重要です。リスクコミュニケーショ ンとは, 食品の安全性を向上させるリスク評価やリスク 管理について，消費者を含む関係者との間で情報の共有 や意見交換を行うことです，食品安全委員会では，国民 の関心の高いリスク評価の内容などについてリスクコ ミュニケーションを行うとともに, リスク管理機関や地 方公共団体と連携したリスクコミュニケーションにも取 り組んでいます。

また, 食品安全委員会 (原則毎週火曜日開催) や専門 調査会などの会合は，原則，公開で行われており，すべ ての議事録をホームページに掲載して透明性の確保に努 めています.

\section{3. 研究および調査事業}

食品安全委員会はリスク評価に必要な研究や調査事業 を毎年行っています．食品安全委員会そのものは研究室 を持っていないのですべて公募，委託しています.

食品健康影響評価技術研究はリスク評価に必要な技術 研究等を行うもので, 基礎的なデー夕収集やリスク評価
方法の開発など新規技術の開発などを行い，2年から 3 年の期間で行うものです。食品安全確保総合調査は, リ スク評価に必要な情報を収集分析する調査事業で，おお むね 1 年で行うものです.

\section{4. 国際協力}

海外のリスク評価機関とは協力文書を締結し連携を 図っています。

EFSA（欧州食品安全機関）, FSANZ（豪州・ニュー ジーランド食品基準機関), ASAE（ポルトガル経済食 品安全庁）ANSES（フランス食品環境労働衛生安全庁）, $\mathrm{BfR}$ （ドイツ連邦リスク評価研究所）FDA（米国食品医 薬品庁, *締結協議中), それ以外にも人的貢献や情報交 換をしている組織としてJECFA（FAO/WHO 合同食品 添加物専門家会議), JMPR (FAO/WHO 合同残留農薬専 門家会議), OECD (経済協力開発機構), Health Canada (カナダ保健省), FSA（英国食品基準庁）FSAI（アイル ランド食品安全庁）があります.

\section{5. 食品衛生行政の監視}

先にも述べましたが, 施策の勧告は, リスク評価の結 果に基づいて行われるだけでなく，重要なハザードが放 置されている場合にも行われます。これまでに勧告が行 われたことはありませんが, リスク評価書には望ましい リスク管理措置や留意すべき事項などを付記することが 行われてきました。

\section{6. 危機対応}

食品安全委員会と消費者庁およびリスク管理機関は, 日頃から密接に連携して食中毒の発生などの情報を収 集・分析し, 国民の健康被害の防止やリスクの最小化に 取り組んでいます。

食品の捸取を通じて重大な健康被害が生じる恐れのあ る緊急事態の発生時には, 政府一体となって対応するの みならず，危害要因についての科学的知見や食品安全委 員会としての見解をマスメディア, インターネットを通 じてタイムリーに国民へ提供します.

\section{7. 食品安全委員会の今後}

リスク評価の新たな手法として既存のデータや新たに 得られたデータを活用し，コンピュータ上 (in silico) で の手法を用いてリスク評価を行っていくことも検討して います。

さらには, 今後のリスク評価を支える人材の育成にも 努めていきます. 